\title{
I Want to Become an Orientalist Not a Colonizer or a "De-Colonizer"
}

\author{
Majid Daneshgar \\ Orientalisches Seminar, Albert-Ludwigs-Universität Freiburg, \\ Freiburg, Germany \\ Majid.daneshgar@orient.uni-freiburg.de
}

\begin{abstract}
Writing Studying the Qur'an in the Muslim Academy emerged out of my personal and academic concerns, which have not been relieved since its publication. Now, my trepidations have become more serious and I am becoming more disappointed about the future of religious and Islamic studies. Such concerns have not disappeared, and all we can do is remind the next generation that their field of study as well as their worldview was shaped in accordance with the proclivity of seniors, superiors, job-givers and policy-makers. The current symposium dedicated to my book, to which this is a response, includes essays by well-versed scholars with Muslim backgrounds. They all draw my attention to the diversity, complexity and importance of the notions we use regularly in the study of Islam. Each of the essays suggests how the discourse on method and theory in the study of Islam has changed within the last decade.
\end{abstract}

\section{Keywords}

orientalism - colonialism - de-colonization - Edward W. Said - orientalist colonizer - de-colonizer

Writing Studying the Qur'an in the Muslim Academy (2019) emerged out of my personal and academic concerns, which have not been relieved since its publication. Now, my trepidations have become more serious and I am becoming more disappointed about the future of religious and Islamic studies. From recent personal experience, there are Muslim professors (in the West) who still 
say "do not share information on a particular topic with another non-Muslim professor" or "why is someone Christian still interested in demystifying the history of the Qur'an, and not the Bible?" This is the way senior scholars control a discipline, influencing junior and emerging scholars by using their power, seniority and connections to expand their territory. They try to rescue their [own] Islamic Studies from the West (others) while being firmly rooted in the West. ${ }^{1}$ Here, exclusivism emanates from inclusive contexts, and illiberalism out of liberalism. Some other obvious examples like the "monitoring of university lecturers" in North America and New Zealand was outlined in my book (e.g., 2019: 134). In line with such bitter experience, we still come across publications of Muslim professors in the West which define the geography of the "heartland of Islam" as being wherever [Sunni] Arabs live and the Arabic language is used in Sunni materials. For them, returning to and reviving the Arab identity is in/directly a priority, ${ }^{2}$ because for a long time our field has been in another state of turbulence, the so-called "sectarian study of Islam" which is "a culture of isolation and the isolation of cultures" (Daneshgar 2019: 71-95). It is hard to be optimistic for a transcultural, philological and profound study of Islam and Islamic culture as long as senior professional and powerful members of academia still view the heartlands of Islam as being in the Arab world. We thus need "taboo-breakers" (Daneshgar, 2019: 1-2).

Such concerns are timeless and endless, and all I or others can do is to remind the next generation that their field of study as well as their worldview might have been both theoretically and politically shaped in accordance with the proclivity of seniors, superiors, job-givers and policy-makers.

The current symposium dedicated to my book, for which I express gratitude, includes essays by well-versed scholars from Muslim backgrounds. They all draw my attention to the diversity, complexity and importance of the notions we use regularly in the study of Islam. Each of the four essays, as Aaron W. Hughes mentions in his foreword, suggests to us how the discourse on method and theory in the study of Islam has changed for the better within the last decade. ${ }^{3}$ This change challenges scholars to be more critical than before. The response by Sajjad Rizvi (Exeter) deals with the methodological and theoretical aspects of my book and raises questions about revisiting, and the general significance

1 See my earlier essay on such concerns (Daneshgar 2018).

2 A shocking example is the recent monograph of El Shamsy (2020: 7) in which he introduces his area of investigation as "Arabo-Islamic scholarly tradition" not those of Persia, India, Malay Archipelago, Africa - unlike his claim, rediscovering classical works was widely practiced in non-Arab contexts. Why did he call his book "Rediscovering the Islamic Classics" as opposed to "Rediscovering the Arabo-Islamic Classics"?

3 Also, see Hughes 2012. 
of, the de-colonialism of Islamic studies. The responses by Lien Iffah Naf'atu Fina (Yogyakarta-Chicago) and Mohsen Feyzbakhsh (Tehran) deal with "different" readings of "Orientalism" in Indonesian and Iranian academic contexts, respectively. Sarah Qidwai's (Toronto), on the basis of her personal and academic experiences, sheds light on my emphasis of the sorts of [modern European] "science" and how they are read alongside the Qur'an in the Muslim academy. Despite touching upon slightly different areas, all essays share a common concern: one's approach to and reading of the other in Islamic studies. As such, I address them all collectively in what followings. My main argument is that being an "Orientalist" might effectively reduce exclusivism and ascend inclusivism in the study of religion in general and of Islam in particular.

Colonialism has been (mis-)interpreted and its functionality has been generalized. We all know that colonization is not a simple physical domination; it involves all sorts of mental and psychological means of subordinating people. It has a lasting, unseen and strong impact which will not leave the spirit of the colonized people: that is imperialism. ${ }^{4}$ Should one fight "Imperialism"? From my background, as one who grew up in the "Orient," we were fed with hundreds of books, magazines, movies and documentaries to realize how our culture, tradition and wealth were exploited by "non-Muslim Christian Europeans" or "they." "So what shall we do?" they asked us. "De-westernize" or "indigenize," or "redact," "eradicate," "negate" or "prohibit" alien (Western and unbeliever) intervention; these are the options they presented. In the Muslim world, these are usually seen as synonyms for "de-colonization." The translation of "de-colonization" in the Muslim academy is, again, different from that of a liberal context. Our hearts and minds were infused with the danger of the "universalization of whatever is Western" which unscrupulously penetrates every part of the Islamic educational system. So Muslims, "we", should be aware of westerners, "they," everywhere, at all times. As such, an Islamic version of "de-colonization" emerged.

De-colonization is neither plausible nor feasible. For me, as I outlined in my book, the clash of methodologies, objectives, as well as of theories (2019: 137) still builds a wall between one's understanding of a religious/traditional topic whether on this or that side of the wall. De-colonization, being viewed as a form of de-westernization, in the Muslim academy controls race, religion,

4 Historical aspects of "colonialism" and "imperialism" are comprehensively described in Kohn and Reddy 2017. 
method, theory and culture. Once one (say, a Muslim believer) classifies the study of Islam into "good" versus "bad", "pious" versus "impious," or "hostile" versus "sympathetic" rather than "academic" versus "apologist," or "polemics" versus "non-polemic," it does not matter where they live, be it in the core lands of Islam or at the heart of Christendom, their de-colonization will not equate with "inclusivism." Even founding academic ties (which is actually political) ${ }^{5}$ between Muslim and non-Muslim institutions, like that outlined by Qidwai, will not tone down apologist and polemic views. Here, "de-colonization" acts similarly to "colonization"; both work on the assumption of the exclusion of "otherness."

For Rizvi, "it is too easy to conflate decolonisation (and postcolonialism) as an extension of the most uncharitable reading of Orientalism." However, Said's critique of Orientalism (Said 1978; see, Daneshgar 2020), and the subsequent misreading of the Orientalists' endeavor, is what currently and more significantly forms Muslim perception of the West and Western theories:

Albert Hourani wrote me in March 1992, a few months before his untimely and much regretted death, due to the force of my argument (for which he said he could not reproach me), my book has the unfortunate effect of making it almost impossible to use the term "Orientalism" in a neutral sense, so much had it become a term of abuse.

SAID 1978: 340

Rizvi's thesis raises a global concern: "what should be done for and in the study of Islam?" He then provides us with a prescription. My book's question is completely different: "what was/is going on in the study of Islam in the Muslim academy?" My book addresses the suffering of self and others from ignorance and marginalization and is about factual academic incidents and possible outcomes. I try to show how critical discussions on Islam, especially when it comes to the study of the formative era of Islam, move faster and are sharper and more transferable in private and independent circles than in those academic ones where "the authorities have more control":6

5 They are political, because they have common Muslim-Western academic contexts (like that of Tehran-McGill) founded during the peaceful political relationship between Iran and Canada before the revolution of 1979. Moreover, a number of people teaching Islam in the Iranian academy are graduates of Canadian universities, including McGill (Daneshgar 2019: 145).

6 On the influence of private circles, see Sarah Qidwai's response above. 
Outside the academic context and in the private sphere, over which the authorities have less control, people argue that Muhammad loved the wife of his son. They know that this is a controversial topic which needs to be expressed cautiously. Many of them declare their opinion on the basis of classical sources, including The History of al-Tabari, a work which is not particularly admired by Muslim fundamentalists.

DANESHGAR 2O19: 65

One may now wonder why pluralistic contexts are not more specifically examined in my book. ${ }^{7}$ While writing, I was fully aware of the diversity of the Muslim academy, but I did not then and still do not think now that it would challenge my main thesis that "Irshadic Power"- "which has the potential to impact all community members in all parts of their lives, including academia, politics, and religion"-or whether or not one is connected to either Sunnism or Shi'ism, influences the reading of Orientalism.

To me, an Islamicist reading of the Orientalist tradition should be revisited. How many Muslim academic institutes, for example, examine the type of Islamic studies created by Orientalists in the aftermath of Said's Orientalism $(1978)$ ? As I have already emphasized, his work emerged as a significant corrective and important contribution to the world order, but given all its selectiveness and structural defects, I wonder why courses on "Orientalism," "Qur'an and Orientalism" or "Orientalism and Occidentalism" have been developed in the Muslim academy in general and in Indonesia in particular since the 1980s? All these courses and programs share a common Saidean concern, namely, why and how western scholars [i.e., "they"] read Muslims' [i.e., "our"] religion? Such questions have led many to fall into a trap, of which Said himself warned in his Orientalism, that of Occidentalism: "I hope to have shown my reader that the answer to Orientalism is not Occidentalism" (Said 1978: 328 ). However, his statement was not seriously taken into account by his acolytes.

Regardless of methodological and theoretical incompatibilities between the Muslim and Western study of Islam, there is a small commonality between the two approaches. The Muslim one was initiated as a part of the Saidean legacy, and that of the West as a Saidean postcolonial approach leading to de-colonization. Either way, a large part of Orientalist literature was and remains forgotten. Generally, Orientalists' study of the Orient was carried out by thousands of people mainly from 16oo-1930s. ${ }^{8}$ Examining manuscripts, early

7 See Lien Iffah Naf'atu Fina's response above.

8 Of course, this is a longer and older tradition, but we place particularly emphasis on these period. 
printed volumes and modern European translations of Muslim literature in the special collections of different libraries for a couple of years showed me how many titles - many of them still new and untouched - remain unstudied on account of being produced during the colonial era (e.g., Daneshgar and Kerr 2017). The origin of this problem is common, too: both sides-the Muslim and the Orientalist - are used to ignore wider bodies of literature. As I demonstrated in my work, sources produced in Shici lands are not taken into account in Sunni ones, and vice versa. The situation is barren for Sufi and Ismaili contexts. And by "sources" I do not mean those famous works of "Nasr and al-Attas" (Daneshgar 2019: 7) or what I have already mentioned as "those of religious elites" (5).

The way Islam is globally and transregionally studied should be reformed bottom-up, not top-down. We need to see (not anthropologically but literarily) how ordinary Muslim and non-Muslim students, junior and emerging scholars approach Islam, and to what extent they limit their proximity with former elites and senior scholars who have not only misread the literature, but also ignored it. An example is the significant contribution of non-Muslim (i.e., Orientalist) scholars who work in Quranic exegetical studies (widely known as Tafsir studies). Since the mid twentieth century their points have been reiterated by [a large number of] Muslim scholars of exegesis ... the latter group are now about to lead the field because they have simply promoted their works through a particular number of [intimate] journals and publishers without citing earlier literature produced by non-Muslims (others) (see Daneshgar 2020). Instead of following up on previous scholarly works, they aim to get Quranic exegetical studies tradition back from Western scholars, including, among others, Ignác Goldziher, David S. Margoliouth, Jane D. McAuliffe, Anthony Johns, Andrew Rippin, Peter G. Riddell, among others.

Said's reduction of the Orient and its literature to the Arab world (which is Isti'rab not Istishraq) has affected both Muslim and Western scholars who wish to de-colonize Islamic studies. "De-colonization" of the world order may well be a good thing if it is not limited to, for example, a "European/Western picture of the world." It must also evaluate, reexamine and even deconstruct other communities who are usually and wrongly labeled as "inferior," "enslaved," or "suppressed." De-colonization, like the one Rizvi wishes to see performed, must be a comprehensive mechanism that-before forging a path of integration, universalization, inclusivism and "pluriversalism" - should thoughtfully go through Muslim, Chinese, Indian, South American and Japanese reading of the same world.

However, covering the entire "Orientalism tradition" as representative or a part of colonization is again falling into the same trap, namely, "a top-down 
consideration of the study of Islam." Orientalism (unlike recent Muslim Occidentalism) was not a pure imperially- and/or inferiority-oriented project. It was replete with thousands of unknown scholars who have largely been forgotten in our top-down approach to Islamic studies: these include travel reports, periodicals, translations, and often times provocative hypotheses. Most of these are largely ignored, forgotten, and buried. An entire network of knowledge, passion and innovation has disappeared alongside these works.

The Orientalist tradition, I want to suggest, is inclusive and pluralistic enough that it need not be de-colonized. It is a tradition that ought to encourage both authors and readers to bravely (not politically) critique and complete each other's work. If one wants to decolonize "Orientalism," it will not end successfully. We observe today that many scholars of Islam have tended to pay extra attention to the Arabic language-materials (not literature and literary works) while ignoring other Asian languages and literature. They are practically demolishing philological castles built by groups of scholars and scientists over the course of history, with the aim of building a new imaginary, that of "de-colonized Islamic Studies." It is unnecessary, in my opinion, to invest extra time and energy to "de-" something scholarly from the 17th to the 2oth centuries. We instead need to "re-" view them, or possibly separate them "piece by piece," without necessarily overlooking and destroying them. The claim to decolonize the study Islam is barren because Oriental and Asian languages - the main stuff of Orientalism — are rarely taken into account by a large number of de-colonizers!

An Orientalist can be anyone interested in the history, culture and connections of African-Asian worlds with a scholarly passion. One does not need to be in the Orient. For Orientalists, there is a wide network of Islamic and non-Islamic terms, phrases and works which are tightly interconnected. Pieter Johannes Veth (1814-1895) was a well-known and prolific Dutch scholar, literary figure, geologist, ethnographer, and scientist known for his encyclopedic knowledge, proficiency in European and Asian languages and, more importantly, anti-imperial approach. He never visited the Dutch East Indies, but his studies, reviews and commentaries on the Malay-Indonesian world (particularly Java) were instrumental in enlightening his Dutch readership; allowing them to imagine Southeast Asia and providing them with a broader and clearer picture of where their fellow countrymen served. As mentioned in Paul van der Velde's homepage (http://www.paulvandervelde.nl/english/), he is also known because of "[his 1882-] three-volume magnum opus 'Java, Geographical, Ethnographical and Historical' (Java, Geographisch, Ethnographisch, Historisch) consisting of approximately three thousand pages."-While being a constant absentee from the Archipelago, Veth was a pioneer who coined the term 
"Persian-Shīism" (Perzisch-Sjiietische) within the context of Malay Islam and Indonesian Shi' ism while examining the origin of the traditional and local feast known as Tabut, dedicated to the commemoration of the death of Husayn and his older brother, Hasan. Such innovations are not imaginary but philological (Veth 1888). Orientalism, in such a sense, is passion-based not power-based.

Another example is Nathaniel Bland Esq., (formerly Crumpe; 1803-1865) who was a Persian language scholar at Oxford, and also a first-class cricketer. He produced a selected commentary (1844) on Makhzan al-Asrar, The Treasury of Secrets: Being the First of the Five Poems, or Khamsah, of Sheikh Nizami, of Ganjah. ${ }^{9}$

Orientalists' works are brimming with scholarly, philological and terminological analyses. One may expect to find "ugly" and "beautiful" points alongside each other. But neither proves nor signifies one's enmity or friendship with Islam, or with Muslims and Asian communities. A short look at the following examples would allow us to reexamine how bottom-up orientalism works and that it is not an imaginary project but a philological, contextual, and factual one not limited to Europeans but inclusive of Muslims, too:

A) "Tafarsh, a place between Kazvin and Hamadan: the inhabitants are accused of being an evil-minded and turbulent race" (Isfahani 1832: 16). Commentary: One impressed by the Saidean legacy would probably consider this as an "Orientalist" attack. However, this is based on the work by Muslim 'map-maker' Sadiq Isfahani who was an orientalist, making the "Map of the Inhabited Quarter" at the Mughal court for Shah Jahan in 1647. His Persian works including Tahqiq al-I'rab and Taqwim al-Buldan survived and were printed for the Oriental Translation Fund of Great Britain and Ireland. The Fund was founded under the auspices of the Royal Asiatic Society in 1828 for the purpose of financing the translation and printing of Oriental works in English; George IV was their patron. Isfahani was probably influenced by former Oriental scholars, among others, Nasir al-Din al-Tusi (d. 1274 AD), Isfahani (d. c. 1349 AD) and Ulugh Beg (d. $1449 \mathrm{AD})$. A new generation of oriental orientalists has now emerged in the West. We may name, among others, Khodadad Rezakhani (Princeton/Leiden) and Shervin Farridnejad (Berlin/

9 Among other works is "On the Muhammedan Science of Tâbír, or Interpretation of Dreams", which is a pioneer work in Islamic Occult Science. However, it is still disregarded in recent works. 
Vienna) who, using their profound philological expertise, shed light on less-examined area of the Orient.

B) "One of the men had with him an ostrich eggshell slung in a sort of network, and used like a gourd to hold water. He told me that ostriches are common in the Nefud [...] on one of the rocks I noticed an inscription, or rather pictures of camels and horses, cut on a flat surface about five feet across. We could not, however, under the circumstances, copy it (pp. 126-127) [...] Nassr, the best of the elder generation, resembled some small Scottish laird, poor and penurious, but aware of having better blood in his veins than his neighbours - one whose thought, every day in the year but one, is of how to save sixpence, but who on that one day shows himself to be a gentleman, and the head of a house (129-130) [...] In England we might perhaps not have been received at all, while here our welcome had been perfectly honest at starting, whatever the afterthought may have been" (Blunt 1881; 1985).

Commentary: This is from a travel account by Lady Anne Blunt (1837-1917) from her journey with her husband, Wilfrid Scawen Blunt, in central Arabia which began in 1878 . One may be surprised how much helpful zoological, literary and philological information this rare account can provide about the history of central and hard-to-cross Arabia before it became industrially and technologically modern. It suggests that ostriches used to live in Arabia and that there were inscriptions showing livestock (an'am) which have been recently examined by Arabists and philologists, among others, Ahmad al-Jallad. It also reflects on an Orientalist's passion to describe her observations and compare them with her memory from her homeland in Europe.

C) "For the Ethnology, of any given region the first requirement is a full and accurate description of each tribe in it, and in the adjacent and connected regions, as it exists at present and has existed in recent or historical times. This embraces the geographical limits and the numbers of the tribe, the Physical Geography of its locations, and its relations of all kinds to intermixed, surrounding, and more distant tribes. The environments of the race thus ascertained, the individual man must be described in his Physiological and Mental Characteristics and in his language. The Family in all its peculiarities of formation and preservation, the relative position of its members, 
its labours and its amusements, must next be studied [p. 108]. It is a most peculiar feature with these people that the marriage law exists at all; and further, the stringency which attaches to it is astounding. Polygamy is allowed, but is seldom practised; while the punishment for adultery is death - usually carried out by a relative, who invites his victim to a hunting excursion, and, after tiring him out, beats his brains out with a club while he is asleep, and leaves him to rot on the earth denying to his remains the rough sepulture given to those who die in an honourable way, whose remains are laid on a $\log$ of wood, in a sitting posture, and buried a foot or two under the ground ..." (1878: 112).

Commentary: the "miscellaneous notices" section of the Journal of the Straits Branch of the Royal Asiatic Society (July, 1878) includes information about marriage law and adultery punishment in the 19thcentury Indonesia which as yet has not been examined seriously.

D) "Acheh is the correct name of that part of Sumatra extending from Tamiaug Point on the East to Trumun on the West Coast, though it is commonly, but erroneously, known to Europeans as Acheen. VALENTYN, however, writing as long ago as 1688, has exposed this misnomer. It is derived from the Hindustani word Achai meaning fine, or lovely, and is so called on account of the exclamation alleged to have been uttered by the first visitors from India on sighting the coast in general and Kampong Pandei in particular" (1880:38).

Commentary: this phrase by G. P. Tolson from the Journal of the Straits Branch of the Royal Asiatic Society (June 1880) displays to what extent Europeans' understanding of Asia is interrelated with that of Asians.

Welcoming and embracing all sorts of local and alien materials and expressing them in simple language is the main part of Orientalist discourse. A large number of studies by Orientalists are already comprehensive and flexible to all sorts of culture and so their study of Islam need not to be "decolonized". De-colonization of Islamic studies or religious studies reminds of a rather "old" and "politically-based" [Islamized] mottos of "De-Hellenization," which has not yet been, and apparently cannot be, successful. ${ }^{10}$ However, the Muslim academy about which I have written the book is not only interested

10 For a (naïve) interpretation of the difference between "Orientalism" and "Hellenism" see Said's afterword written in 1994 attached to his 1978's Orientalism (p. 342). 
in de-colonization but also in de-Hellenization. The latter has been a topic discussed among Muslim philosophers and theologians for many years: ancient Greek culture against (not along with) Asian culture, or more superficially: Aristotelian philosophy vs. Avicennan philosophy not Aristotelian philosophy in line with Avicennan philosophy. A confrontation and clash with the West, at least in terms of methodology, is what the Muslim academy run by "authorities and religious parties" — not brave thinkers—seeks to achieve.

As I explicitly addressed in my monograph "the conversion of brilliance and daring to caution and fear, from the advancement of knowledge to selfpreservation"' (Daneshgar 2019: 140; also Said) is extensively growing for the sake of both career and ideology. Since the publication of my book, I have been informed about the increasing censorship and marginalization of critical works by "reputed" academic publishers as well as editors. Lien Iffah Naf'atu Fina's claim that such things have not happened in Indonesian contexts has perhaps overlooked my statements on the rejection of my own solicited review by one of the most famous (not necessarily good) British journals in the British Isles as well as the way Riddell was questioned during his speech in Malaysia. Perhaps, again, she ignored my definition of "critical piece", that is about feeding freedom and liberty while challenging fundamental Islamic beliefs, as well as those attacks on Abdolkarim Soroush in Iran and Nasr Hamid Abu Zayd in Egypt, or even "the policy of stick and carrot" (Daneshgar 2019: 19). I can never forget the way I was seriously questioned by Muslim colleagues in Southeast Asia when I wanted/agreed to publish articles by Gabriel Said Reynolds entitled "Presentation of Christianity in the Qurān" and Emran El-Badawi's "Qur'an, hadith and church canon." One may also wonder if she could explain about the level of freedom in Aceh, where Shari'a law is taken into account strictly.

I agree, as I repeatedly declared in my book, that the reception of western Islamic studies, translation movement, and methodological flexibility in Iran and Indonesia are far more advanced than other Muslim communities. However, I still wonder why, and ask this question to both Lien and Mohsen Feyzbakhsh, in both Indonesian and Iranian contexts are Wansbrough's Quranic Studies, David Powers' Zayd, or Shoemaker's The Death of a Prophet not translated at all? Instead, both markets are replete with the studies of Fazlur Rahman, Farid Esack, and Abdullah Saeed. Such questions become more serious when one observes that the "one-sided critical" dissertations on Christoph Luxenberg's "The Syro-Aramaic Reading of the Koran" are awarded international Research Awards in the Muslim world. Relatedly, I and a colleague were once requested by a famous Muslim professor in North America to EXCLUDE one of the editorial members who was, according to them, pro-Luxenberg (see Daneshgar 2018). This is despite the fact that although a 
few Aramaic and Syriac circles have been formed in the Muslim world (e.g., Iran), they are not part of the syllabus in departments of Qur'an and Hadith. Similarly, hundreds of English, French and German books on Muhammad are not comparable with one that defends him and which received an award from an Islamic-based society in North America!

The Orientalist tradition is not exclusive but inclusive; it is philological- and passion-based not power-based; it stimulates brilliance and daring through examining various cultures not through negating the "otherness". Orientalism does not need to be changed, and one should not try to return to it. However, it should be reviewed, improved and continued.

\section{Acknowledgements}

I thank Deutsche Forschungsgemeinschaft (DFG) (Projekt number 415543504) for providing me with this opportunity to write this essay.

\section{References}

Blunt, Lady Anne (1881). A Pilgrimage to Nejd, the Cradle of the Arab Race: A Visit to the Court of the Arab Emir and "Our Persian Campaign". London: John Murray [new edition (1985). Introduction by Dervla Murphy. London: Century Publishing].

Daneshgar, Majid and Donald Kerr (2017). Middle Eastern and Islamic Materials in Special Collections University of Otago. Dunedin: University of Otago Library.

Daneshgar, Majid (2018). Censored manuscripts, censored intellects: Can we trust the past?. Mizan. Online at: https://mizanproject.org/censored-manuscripts-censored -intellects/.

Daneshgar, Majid (2019). Studying the Qur'an in the Muslim Academy. New York: Oxford University Press.

Daneshgar, Majid (2020). Lost orientalism, lost orient, and lost orientals: an overview. In Majid Daneshgar and Aaron W. Hughes (eds.), Deconstructing Islamic Studies, 338-357. Cambridge, Mass: ILEX and Harvard University Press.

El Shamsy, Ahmed (2020). Rediscovering the Islamic Classics: How Editors and Print Culture Transformed an Intellectual Tradition. Princeton and Oxford: Princeton University Press.

Hughes, Aaron W. (2012). The study of Islam before and after September 11: A provocation. Method and Theory in the Study of Religion 24 (4-5): 314-336. 
Isfahani (1832). The Geographical Works of Sádik Isfaháni. Translated by J. C. from Original Persian Mss. in the Collection of Sir William Ouseley, the Editor. London: Printed for the Oriental Translation Fund of Great Britain and Ireland.

Kohn, Margaret and Kavita Reddy (2017). Colonialism. In Edward N. Zalta (ed.), The Stanford Encyclopedia of Philosophy. Online at: https://plato.stanford.edu/archives/ fall2017/entries/colonialism.

Miscellaneous Notices (July, 1878). Journal of the Straits Branch of the Royal Asiatic Society (1): 112.

Nizami of Ganjah (1844). Makhzan Ul Asrar, the Treasury of Secrets Being the First of the Five Poems, or Khamsah of Shaik Nizami of Ganjah: Edited from an Ancient Manuscript, with Various Readings and a Selected Commentary by Nathaniel Bland. London: Printed for the Society for the Publication of Oriental Texts.

Said, Edward W. (1978). Orientalism. New York: Vintage.

Tolson, G. P. (1880). Acheh, commonly called Acheen. Journal of the Straits Branch of the Royal Asiatic Society (5): 37-5o.

Veth, Pieter J. (1888). Opmerkingen naar aanleiding van het opstel, Hat Hassan-Husain of Taboetfeest te Benkoelen. Internationales Archiv für Ethnographie (1): 230-233. 